\title{
PERANCANGAN E-COMMERCE BAHAN BANGUNAN PADA PT. INDO METRO SURYA ANDOLA BERBASIS WEB
}

\author{
Yashinta Rizky Febriani ${ }^{1)}$, Sudarmaji ${ }^{2)}$, Dedi Irawan ${ }^{3)}$ \\ ${ }^{\left.1-3^{*}\right)}$ Program Studi IImu Komputer, Fakultas IImu Komputer, \\ Universitas Muhammadiyah Metro
}

Jalan Gatot Subroto No. 100, Yosodadi, Metro Timur, Kota Metro

\begin{abstract}
Abstrak - Pengelolaan proses jual beli produk barang bahan bangunan dapat memakan banyak waktu karena perlu pengecekan barang yang harus dilakukan secara langsung ke toko. Pemanfaatan sistem informasi penjualan dan pembelian produk barang bahan bangunan berbasis web dapat menghemat waktu dan tenaga, karena proses sudah dilakukan menggunakan komputer. Penelitian ini bertujuan untuk: membuat sistem informasi E-Commerce berbasis web di PT. Indo Metro Surya Andola, yang diharapkan dapat membantu dan mempermudah pelanggan serta petugas toko dalam pengolahan data transaksi yang terjadi seperti jual beli produk barang, stok barang, gambar dan harga produk barang, serta dalam pembuatan laporan penjualan. Tujuan penelitian yang dilakukan di PT. Indo Metro Surya Andola adalah merancang sistem informasi E-Commerce pada PT. Indo Metro Surya Andola menggunakan metode SDLC. Penulis menggunakan metode Software Development Life Cycle (SDLC) yang dapat memberikan gambaran input dan output yang jelas untuk satu tahap ke tahap selanjutnya. Sistem informasi E-Commerce dirancang dengan menggunakan pendekatan terstruktur, serta pengujian menggunakan teknik Black Box Testing. Pembuatan sistem informasi termuat dalam laporan skripsi yang berjudul "Perancangan E-Commerce Bahan Bangunan Pada PT. Indo Metro Surya Andola Berbasis Web".
\end{abstract}

Kata Kunci: Perancangan, Sistem Informasi E-Commerce, Software Development Life Cycle (SDLC), Pendekatan Terstruktur.

\begin{abstract}
The management of the buying and selling process of building material products can take a lot of time because it is necessary to check the goods that must be done directly to the store. Utilization of web-based sales and purchase information systems for building materials can save time and effort, because the process has been done using a computer. This study aims to: create a web-based E-Commerce information system at PT. Indo Metro Surya Andola, which is expected to help and facilitate customers and store clerks in processing transaction data that occurs such as buying and selling of goods, stock of goods, pictures and prices of goods, as well as in making sales reports. The purpose of the research conducted at PT. Indo Metro Surya Andola is designing an E-Commerce information system at PT. Indo Metro Surya Andola uses the SDLC method. The author uses the Software Development Life Cycle (SDLC) method which can provide a clear picture of input and output from one stage to the next. The E-Commerce information system is designed using a structured approach, as well as testing using the Blackbox Testing
\end{abstract}


technique. The creation of an information system is contained in the thesis report entitled "Designing E-Commerce Building Materials at PT. Indo Metro Surya Andola Web-Based".

Keywords : Design, E-Commerce Information System, Software Development Life Cycle (SDLC), Structured Approach

\section{PENDAHULUAN}

Perkembangan teknologi saat ini semakin pesat. Dari hari ke hari teknologi terus berkembang, salah satunya adalah internet. Internet merupakan suatu sarana informasi dan komunikasi yang cepat dan akurat. Hal ini membuat banyak pihak memanfaatkan media internet untuk berbagai macam kepentingan, salah satunya untuk kepentingan bisnis. Mulai dari pengusaha kecil hingga perusahaan yang besar memanfaatkan kemajuan teknologi internet sebagai media yang berfungsi untuk mempromosikan produk atau iklan melalui internet. Selain digunakan untuk media promosi, internet juga dapat digunakan sebagai media penjualan dan pembelian produk, jasa dan informasi yang disebut dengan e-commerce.

PT. Indo Metro Surya Andola adalah usaha yang bergerak dalam bidang penjualan bahan bangunan dengan berbagai jenis. Kegiatan pemasaran dan proses penjualan pada PT. Indo Metro Surya Andola masih manual, dimana para pembeli harus datang langsung ke toko untuk membeli ataupun sekedar melihat-lihat produk yang tersedia di PT. Indo Metro Surya Andola. Kegiatan promosi nya juga masih sebatas mulut kemulut atau pun mengharapkan promosi dari pelanggan yang telah membeli produk di PT. Indo Metro Surya Andola. Sehingga kendala yang dihadapi toko saat ini yaitu sulit untuk memasarkan atau menjual produk-produknya ke luar kota, kurang nya pembaharuan informasi produk yang baru, dan hal itu berdampak pada kurang maksimalnya pemasukan toko. Permasalah yang terjadi pada PT. Indo Metro Surya Andola adalah sulit untuk mempromosikan produk yang masih dari mulut ke mulut dan masih sangat terbatas atau sulit untuk menjual produk-produknya ke luar kota, kurangnya adanya informasi yang berbasis web, sehingga masyarakat harus datang langsung ke toko PT. Indo Metro Surya Andola. Pembaharuan informasi produk yang baru, dan hal itu berdampak pada kurang maksimalnya pemasukan toko tersebut harus diminimalisir agar mempermudah toko dalam memasarkan produk, memberikan informasi produk baru dan membuat harga lebih kompetitif karena harga telah tertera pada informasi produk yang berbasis web sehingga menarik minat pembeli.

Berdasarkan latar belakang diatas penulis dapat merumuskan permasalahan mengenai sistem informasi kepegawaian yakni:
a. Bagaimana
merancang
E-Commerce Business to Customer pada PT. Indo Metro Surya Andola ini.
b. Bagaimana mengimplementasikan suatu website E-Commerce yang efisien dan bermanfaat.
c. Bagaimana merancang promosi penjualan tentang pengolahan data dengan menggunakan bahasa pemrograman PHP dan database MySQL.

Tujuan yang ingin dicapai oleh penulis melalui penelitian ini adalah sebagai berikut:

a. Menganalisa sistem promosi dan 
penjualan yang saat ini sedang berjalan di PT. Indo Metro Surya Andola.

b. Merancang E-Commerce yang baik sebagai media penjualan online pada PT. Indo Metro Surya Andola

\section{KAJIAN PUSTAKA DAN LANDASAN TEORI}

Pengertian Sistem

Saragih, A., Simarmata, E. R., \& Maslan, J. (2015:33) : "Perancangan adalah satu langkah untuk memberikan gambaran secara umum kepada manusia atau pengguna tentang sistem yang diusulkan". Sedangkan definisi dari penulis lain "Perancangan merupakan langkah pertama di dalam fase pengembangan rekayasa suatu produk atau sistem".

\section{Perancangan Sistem}

Dodo Zaenal Abidin (2015:4) : "Perancangan sistem didefinisikan sebagai penggambaran sistem secara umum / global kepada calon pengguna (user) tentang sistem yang akan dibuat dan berfungsi untuk persiapan tahap desain / perancangan sistem secara terinci".

\section{E-Commerce}

Candra Ahmadi dan Dadang Hermawan (2013:7) mendefinisikan E-commerce sebagai berikut : "Penjualan atau pembelian barang dan jasa, antara perusahaan, rumah tangga, individu, pemerintah, dan masyarakat atau organisasi swasta lainnya, yang dilakukan melalui komputer pada media jaringan".

\section{Penelitian Sejenis}

Penelitian sejenis merupakan salah satu data pendukung dari penelitian terdahulu yang relevan dengan permasalahan yang dibahas dalam penelitian ini, sehingga data ini dapat menjadi acuan dalam penelitian ini.

\section{Website}

Wahana Komputer (2006:2), "Website merupakan fasilitas hiperteks untuk menampilkan data berupa teks, gambar, suara, animasi, dan data multimedia lainnya".

\section{Alat Bantu Pemodelan Sistem}

Rumbaugh, Jacobson, dan Booch didalam jurnal Erick Fernando (2012:5), menyatakan bahwa : "Unified Modeling Language (UML) merupakan bahasa pemodelan visual yang bersifat general purpose yang digunakan untuk menspesifikasikan, memvisualisasikan, membangun, dan mendokumentasikan artifak - artifak dari sebuah sistem perangkat lunak".

\section{XAMPP}

Nugroho (2013:1), menyatakan bahwa : XAMPP adalah paket program web lengkap yang dapat dipakai untuk belajar pemrograman web, khususnya PHP dan MySQL yang diunggah secara gratis dan bisa dijalankan di semua semua operasi seperti windows, linux, solaris, dan mac.

\section{METODE}

Rosa A.S dan Shalahudin (2014:25), menyatakan bahwa System Development Life Cycle (SDLC) adalah proses mengembangkan atau mengubah suatu sistem perangkat lunak dengan menggunakan model-model atau metodologi yang digunakan orang untuk mengembangkan sistem-sistem perangkat lunak sebelumnya. SDLC atau System Development Life Cycle merupakan metodologi yang digunakan untuk perancangan sistem yang baru dari sistem yang lama atau untuk memperbaiki sistem yang sudah ada. SDLC berfungsi untuk 
memberikan gambaran input output yang jelas untuk satu tahap dan menuju ke tahap yang selanjutnya.

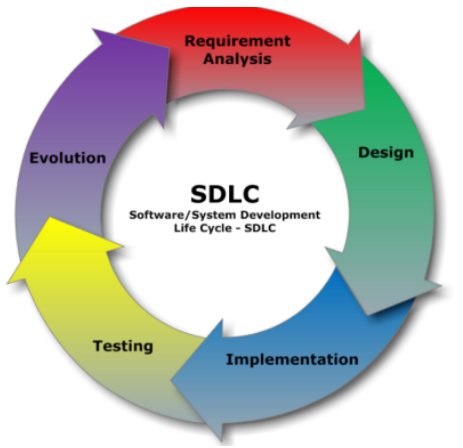

Gambar 1. System Development Life Cycle (Sumber : Ladjamudin 2009)

\section{HASIL DAN PEMBAHASAN}

Sistem informasi yang dihasilkan dari penelitian yang dilakukan di PT. Indo Metro Surya Andola perancangan E-Commerce bahan bangunan.

\section{a. Relasi Tabel}

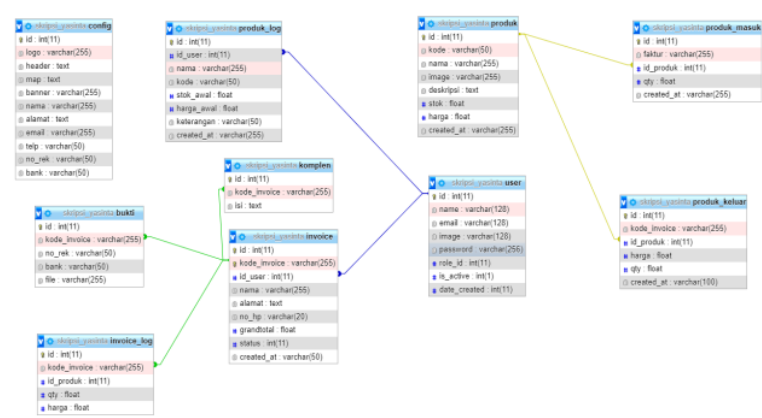

Gambar 2. Rancangan Relasi Tabel

Pada gambar 2 di atas merupakan rancangan database perancangan E-Commerce bahan bangunan dengan relasi tabel, terdapat 9 tabel yang saling berelasi yaitu tabel user, produk log, invoice, bukti, komplain, invoice log, produk, produk masuk, dan produk keluar.

1. Tampilan Halaman Toko Online

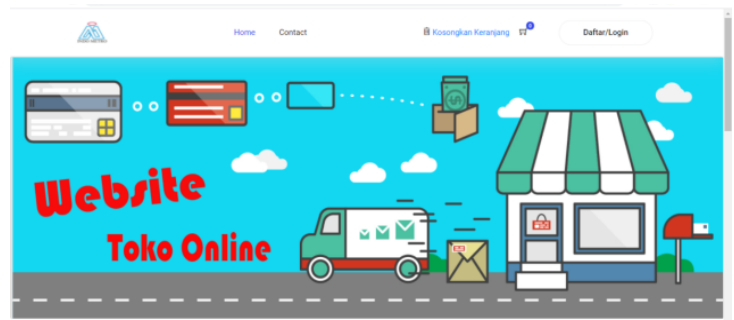

Gambar 3. Tampilan Halaman Toko Online
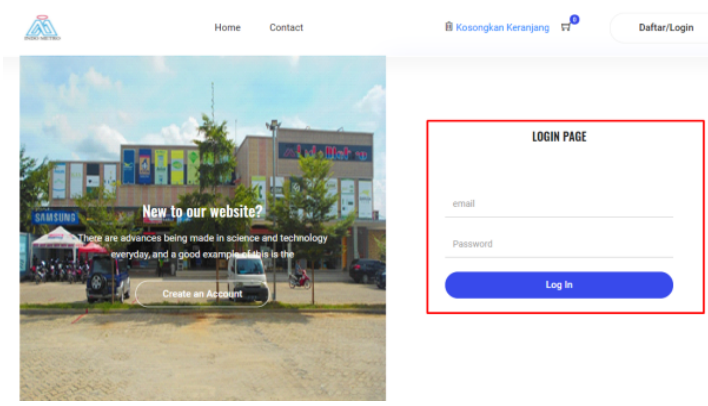

Gambar 4. Tampilan Halaman Login

Pada gambar 3 dan 4 merupakan tampilan halaman login admin dan customer yang berfungsi untuk masuk pada menu dashboard dengan cara menginputkan user dan password.

\section{Tampilan Dashboard Admin}

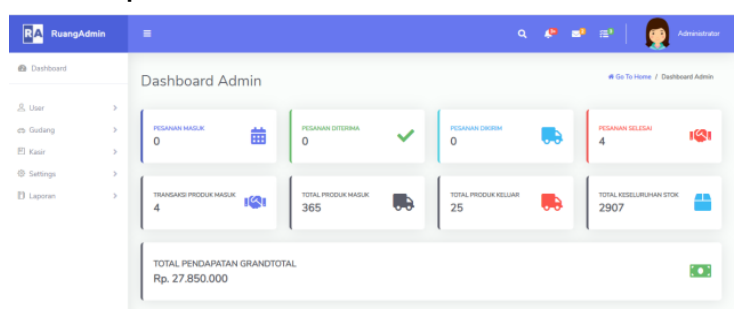

Gambar 5. Tampilan Dashboard Admin

Pada gambar 5 merupakan tampilan halaman dashboard yang merupakan halaman selanjutnya setelah admin melakukan proses login.

\section{Tampilan Dashboard Gudang}

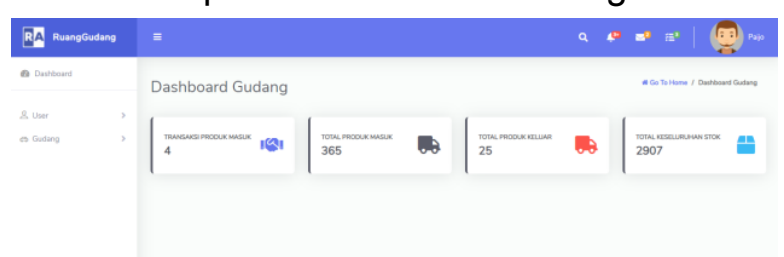

Gambar 6. Tampilan Dashboard Gudang 


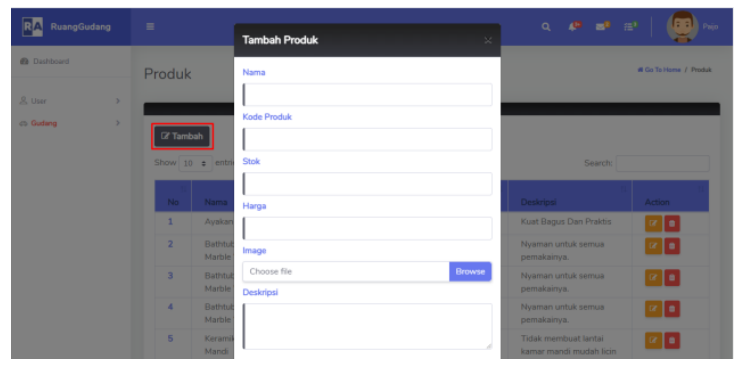

Gambar 7. Tampilan Tambah Produk Barang

Pada gambar 6 dan 7 merupakan tampilan menu input produk barang bahan bangunan.

\section{Tampilan Dashboard Kasir}

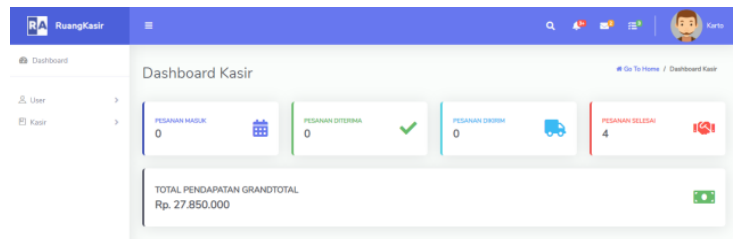

Gambar 8. Tampilan Dashboard Kasir

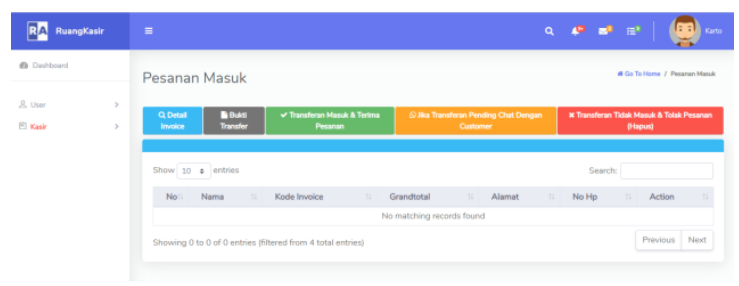

Gambar 9. Tampilan Halaman Pesanan Masuk

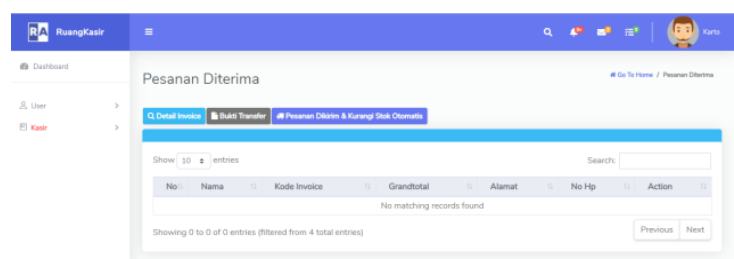

Gambar 10. Tampilan Halaman Pesanan Diterima

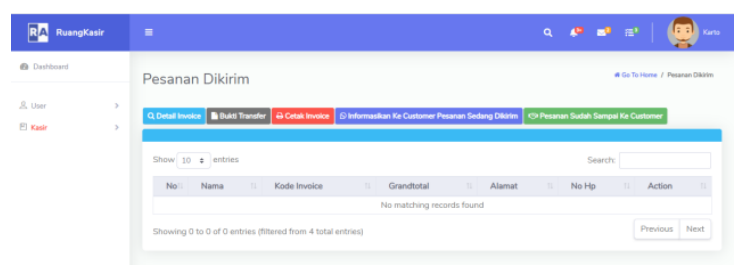

Gambar 11. Tampilan Halaman Pesanan Dikirim

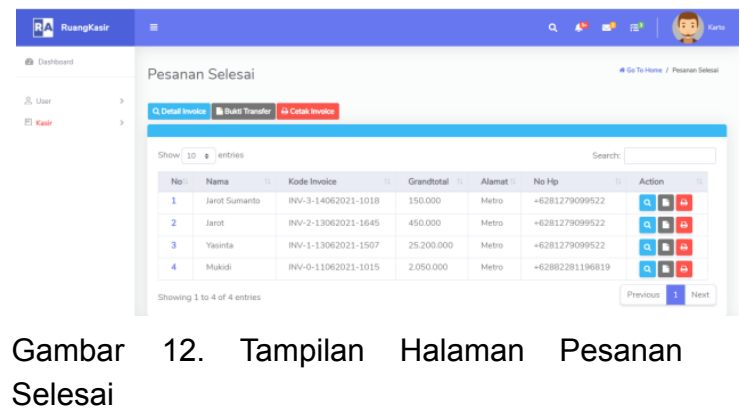

Pada gambar 8 sampai 12 merupakan tampilan halaman pemesanan produk barang bahan bangunan hingga selesai.

5. Tampilan Halaman Draft Customer

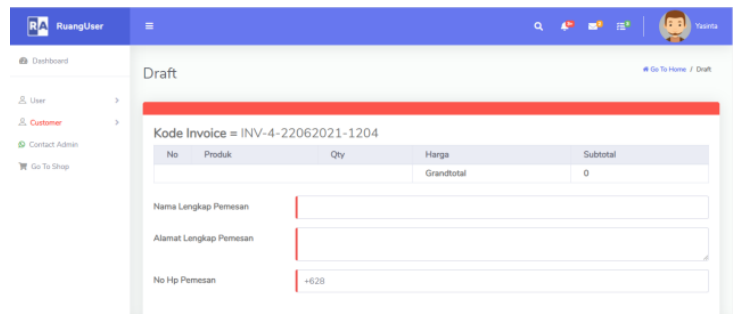

Gambar 13. Tampilan Halaman Draft Customer

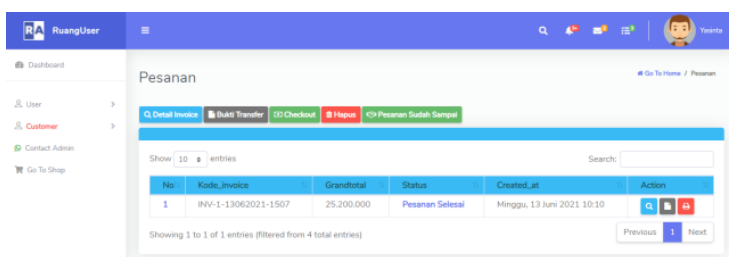

Gambar 14. Tampilan Halaman Pesanan Customer

Pada gambar 13 dan 14 merupakan tampilan halaman dari draft produk barang bahan bangunan hingga pesanan selesai.

6. Tampilan Halaman Faktur Produk

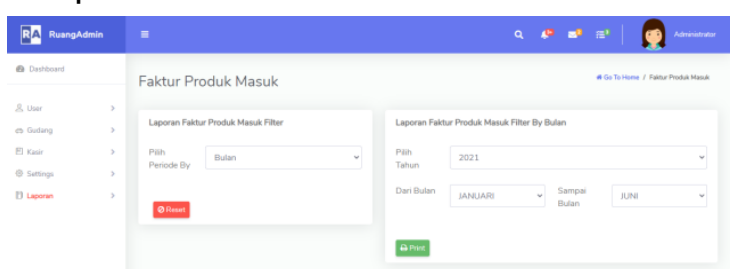

Gambar 15. Tampilan Halaman Faktur Produk 


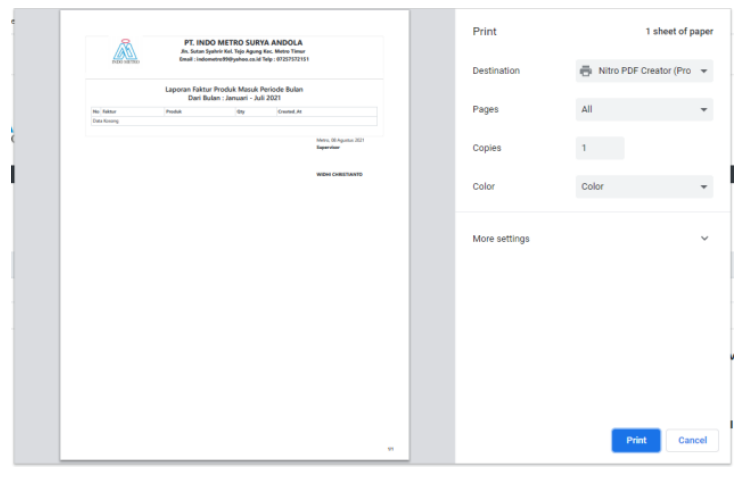

Gambar 16. Tampilan Halaman Cetak Faktur Produk

Pada gambar 15 dan 16 merupakan tampilan halaman faktur produk yang di sortir melalui tanggal, bulan, atau tahun untuk mencetak hasil faktur produk barang bahan bangunan.

\section{KESIMPULAN}

Dari penelitian yang telah dilakukan oleh penulis tentang Perancangan E-Commerce Bahan Bangunan Pada PT. Indo Metro Surya Andola Berbasis Web Menggunakan Metode SDLC, serta pembahasan yang telah diuraikan oleh penulis pada bab-bab sebelumnya, maka dari itu dapat ditarik kesimpulan mengenai sistem yang telah dirancang sebagai berikut:

a. Sistem informasi penjualan ini dibuat untuk mempermudah sistem penjualan secara online tentang produk barang bahan bangunan baik dari gambar, ukuran dan harga.

b. Sistem informasi penjualan yang dapat mempermudah proses bagian staff dalam proses pengecekan stok barang.

c. Dengan adanya sistem informasi penjualan ini pihak PT. Indo Metro Surya Andola akan dipermudah proses penjualan produk barang bahan bangunan pada toko karena bisa diakses kapan dan dimana saja sehingga user atau costumer tidak harus melihat langsung produk barang bahan bangunan ke toko.

d. Sistem yang mempunyai arsip penjualan produk barang bahan bangunan akan disimpan secara elektronik di dalam database.

Sistem informasi penjualan ini memiliki kekurangan yang nantinya dapat dikembangkan lebih lanjut lagi. Saran dari penulis yaitu sistem informasi penjualan ini dapat dikembangkan dengan menambahkan fitur-fitur pesan notifikasi lain untuk dibuatkan estimasi waktu pemesanan. Diberi cashback kepada customer pada saat ada kerusakan barang setelah barang sampai.

\section{REFERENSI}

[1] Rosa A. S. and M. Shalahuddin, Modul Pembelajaran Rekayasa Perangkat Lunak (Terstruktur dan Berorientasi Objek). Bandung, Jawa Barat: Modula, 2001.

[2] Saragih, A., Simarmata, E. R., \& Maslan, J., 2015, Perancangan Aplikasi E-Library Menggunakan Bahasa Pemrograman PHP Pada Universitas Methodist Indonesia. Jurnal TIMES, 4(1), 31-35.

[3] Wahana Komputer, 2006, Panduan Lengkap Menguasai Pemrograman Web dengan PHP 5, Yogyakarta, CV ANDI OFFSET.

[4] Sugiyanto Ikhsan dan Gunardi, "Sistem Informasi Honorarium Berbasis Web Di Dinas Pemakaman Dan Pertamanan Kota Bandung," Co-Management J. IIm. Manaj. Dan IImu Sos., vol. 1, no. 2, pp. 183-196, 2019. 
[5] N. S. Syahrul Mauluddin, "Sistem Informasi Persediaan Dan Penjualan Barang Berbasis Desktop Di D-Net House," Pros. Semin. Nas. Tek. Komput. dan Rekayasa, no. October, pp. III-12, 2017.

[6] A. Suryadi, "Rancang Bangun Sistem Pengelolaan Arsip Surat Berbasis Web Menggunakan Metode Waterfall (Studi Kasus: Kantor Desa Karangrau Banyumas)," J. Khatulistiwa Inform., vol. 7, no. 1, pp. 13-21, 2019.

[7] Mattalitti, M. R.2020. Tinjauan Sistem Informasi Akuntansi Penjualan
Furniture Pada UD. Bawakaraeng Di Kota Sorong (Papua Barat). Economics Bosowa, 5(002), 173-184.

[8] Asrin, E. 2020. Sistem Informasi Administrasi Pengolahan Data PT. Aidil Fitra Kota Jambi Berbasis Web. Fortech (Journal of Information Technology), 4(2), 6-11.

[9] Penjadwalan Dokter Berbasis Web Dengan Menggunakan M. Destiningrum and Q. J. Adrian, "Sistem Informasi Framework Codeigniter (Studi Kasus: Rumah Sakit Yukum Medical Centre)," J. Teknoinfo, vol. 11, no. 2, p. 30, 2017. 